\title{
Determination of the Bioaccumulative Potential Risk of Emerging Contaminants in Fish Muscle as an Environmental Quality Indicator in Coastal Lagoons of the Central Mexican Pacific
}

\author{
Miguel Ángel Arguello-Pérez ${ }^{1} \oplus$, Eduardo Ramírez-Ayala ${ }^{1}$, Jorge Alberto Mendoza-Pérez ${ }^{2}$, \\ María Magdalena Monroy-Mendieta ${ }^{2}$, Miguel Vázquez-Guevara ${ }^{3}$, Carlos Lezama-Cervantes ${ }^{4}(0$, \\ Enrique Godínez-Domínguez ${ }^{1}$, Francisco de Asís Silva-Bátiz ${ }^{1}$ and Adrián Tintos-Gómez ${ }^{1,5, *}$ \\ 1 Department of Studies for the Sustainable Development of the Coastal Zones, University of Guadalajara, \\ Jalisco 48980, Mexico; perezmarguello@gmail.com (M.Á.A.-P.); 357.ramirez@gmail.com (E.R.-A.); \\ egodinez@costera.melaque.udg.mx (E.G.-D.); fasilva@costera.melaque.udg.mx (F.d.A.S.-B.) \\ 2 National School of Biological Sciences of National Polytechnic Institute, Mexico City 07738, Mexico; \\ jmendozap@ipn.mx (J.A.M.-P.); encb_lci@hotmail.com (M.M.M.-M.) \\ 3 Faculty of Chemistry, Guanajuato University, Guanajuato 36050, Mexico; mvazquez@ugto.mx \\ 4 Faculty of Marine Sciences, Colima University, Colima 28868, Mexico; clezama@ucol.mx \\ 5 Renewable Energy Research Center, Technological University of Manzanillo, Colima 28869, Mexico \\ * Correspondence: adrian-tintos@utem.edu.mx
}

Received: 26 August 2020; Accepted: 21 September 2020; Published: 29 September 2020

\begin{abstract}
This research proposes an environmental quality indicator to detect, predict and scientifically evaluate the environmental impact generated by chemical substances within the pollutant group of nonsteroidal anti-inflammatory drugs (NSAIDs) that are categorized as emerging contaminants (ECs) with endocrine disruptive action. The present study was carried out in two coastal lagoons affected by wastewater produced by urban and rural settlements in the states of Colima and Jalisco. Four pharmaceutical compounds were analyzed: diclofenac, ibuprofen, ketorolac and naproxen. The muscle tissues of 14 fish species were analyzed; all had measurable concentrations of the four contaminants. The presence of the ECs was confirmed in all the samples collected. The bioaccumulative potential risk (BPR) of the ECs is estimated by calculating the environmental risk factors and the potential risks to human health, evaluating the concentration and assessing the risk involved in the incorporation of the pollutants into the environment. The BPR indicates the potential impact of NSAIDs on the ecology of these coastal lagoons, and predicts whether a contaminant is likely to act and persist in the environment and bioaccumulate in organisms. Additionally, it estimates the possibility of contamination and risks to human health caused by residues of the chemical contaminants.
\end{abstract}

Keywords: ecotoxicology; NSAIDs; fish muscle tissue; bioaccumulation; coastal ecosystems

\section{Introduction}

As a consequence of the high levels of industrialization and urbanization along river basins, coastal ecosystems have been significantly impacted by a wide range of anthropogenic contaminants [1]. Chemical contaminants, particularly emerging organic pollutants, have been detected in coastal zones at trace concentration levels, which are still harmful to ecosystems [2]. Within this pollutant group are the nonsteroidal anti-inflammatory drugs (NSAIDs), which include the pharmaceuticals diclofenac, ibuprofen, ketorolac and naproxen. These products are biologically active and persistent substances [3]. Due to their volume of consumption and incomplete removal during the wastewater treatment 
processes, NSAIDs are among the most frequently detected pharmaceuticals in treatment plants and surface waters worldwide [4]. This explains their occurrence in the environment, particularly in aquatic ecosystems, which they enter through municipal and hospital wastewater discharges [5].

The consumption of painkillers such as NSAIDs is predicted to increase [6] and their occurrence in the aquatic environment will increase accordingly [7]. The analgesic action of NSAIDs is mainly due to their ability to inhibit the enzymes that synthesize prostaglandins. These compounds have been designed to elicit a specific biological action in the body and often resist inactivation prior to inducement of their intended therapeutic effect, which causes toxicity and bioaccumulation in hydrobionts [8].

Although side effects have not yet been reported during clinical trials in fish, nephrotoxicity, hepatotoxicity and other toxic effects have been reported after chronic administration of diclofenac, ibuprofen, ketorolac and naproxen during ecotoxicological studies. Accordingly, they may accumulate in aquatic organisms and even bio-magnify through the food chain, thus threatening the aquatic ecosystem and potentially harming human health [9]. The toxicity of chemicals in aquatic organisms usually correlates with their uptake and accumulation in tissues [10]. Therefore, it is important to study the accumulation of chemicals in different biological tissues.

Bioconcentration is the accumulation of a substance (dissolved in water) within an aquatic organism. The bioconcentration factor (BCF) of a compound is defined as the ratio of the concentration of the chemical in the organism and in water at equilibrium [11]. BCF values have traditionally assumed that the concentration of a chemical in tissues of aquatic organisms is linearly and independently related to its concentration in water [12]. Bioaccumulation data can be used to support human health risk assessments and ecological risk assessments. Human health risk assessment is the method of estimating the probability of adverse health effects of toxic elements in humans; the human health risk factors of NSAIDs are usually estimated as oral ingestion (food and water), dermal contact (soil) and inhalation (dust), evaluating the ingestion rate, exposure frequency and exposure period. Because muscle tissue is the portion of the fish that humans typically consume, edible tissues (e.g., fish fillets) are recommended to measure chemical contamination [13].

Bioaccumulation refers to the continuous increase in the concentration of a chemical in an organism, compared to the chemical's concentration in the environment to which the organism is exposed, i.e., air, water, soil and food [14]. The bioaccumulative potential risk (BPR) is estimated by calculating the environmental risk factors and the potential risks to human health, evaluating the concentration and assessing the risk involved in the incorporation of the pollutants into the environment.

This research proposes an environmental quality indicator that evaluates the presence of emerging contaminants in fish muscle, their influence on the medium and the potential risks posed by the presence of these pollutants in the environment and possible effects to human health. Therefore, tools that contribute to the protection of water sources and the regulation of pollution in coastal zones can be provided.

\section{Materials and Methods}

\subsection{Study Sites and Sample Collection}

Four ECs of the NSAID group were analyzed: diclofenac, ibuprofen, ketorolac and naproxen. The samples were collected in two coastal lagoons located in the Central Mexican Pacific (Figure 1).

Sampling site "A" (Figure 1) includes the entire Barra de Navidad Lagoon located in the state of Jalisco, southeast of two settlements of 3200 and 4320 inhabitants [15]. Sampling site "B" (Figure 1) comprises the Cuyutlan Lagoon, located in the state of Colima, $8.8 \mathrm{~km}$ southeast of the commercial port of Manzanillo, which reports an approximate population of 184,541 inhabitants [15]. Both lagoons are designated Ramsar sites. They are estuarine environments that include mangroves, brackish/salty systems and are geologically classified as coastal lagoons. The altitude at the study sites varies from 0 to $10 \mathrm{~m}$ above sea level [16]. 


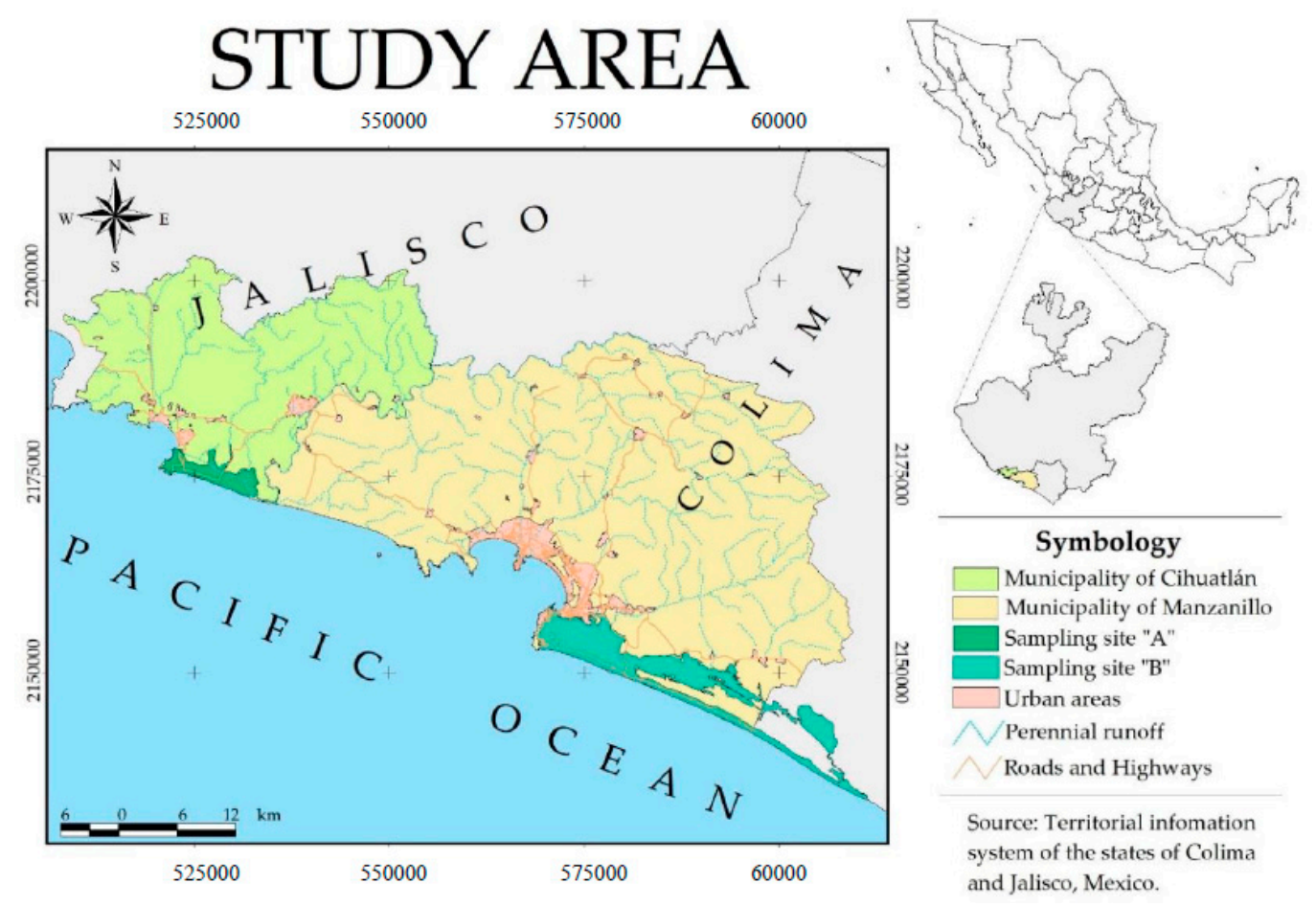

Figure 1. Location of the study area (states of Colima and Jalisco).

To obtain muscle samples, eleven species of fish were selected at site " $\mathrm{A}$ " and seven species of fish were selected at site "B". The fish were collected in the lagoons through traditional fishing arts according the "Fish sampling protocol in continental waters" established in the Mexican Official Standard, NOM-159-SCFI-2012. Four specimens per species were collected; the specimen processing was conducted in accordance with the American Fisheries Society's Guidelines for The Use of Fishes in Research [17]. The complete fish of each species were transported to the laboratory in frozen conditions (near $-10^{\circ} \mathrm{C}$ ) where biometric data (weight and height) were reported. Each fish was partially defrosted (until muscle felt soft) and then muscle tissue samples (all pieces approximately $5.0 \times 3.0 \times 0.5 \mathrm{~cm}$ with skin and scale) were extracted from the ventral muscle of the fish [18]. Samples were individually stored at $-16{ }^{\circ} \mathrm{C}$ to $-18{ }^{\circ} \mathrm{C}$ in Nalgene airtight containers until use.

The fish collected include both resident and transient species in the studied lagoons. Species were selected according to their frequency of occurrence, type of feeding and those that represent commercial interest in the study area.

\subsection{Sample Processing}

The tissue samples were thawed inside Nalgene airtight containers and then minced with an industrial immersion blender (KEF Industrial ${ }^{\circledR}$ BL-40C, İstanbul, Turkey) and finally homogenized as a slurry with a disperser and homogenizer (IKA ${ }^{\circledR}$ UltraTurrax-3593001, Staufen, Germany). All processes were carried out at temperatures below $4{ }^{\circ} \mathrm{C}$. Approximately 25 to $30 \mathrm{~g}$ of slurry from each fish specimen were mixed with $200 \mathrm{~mL}$ of dicholoromethane-methanol solvent mixture (40:60), with Supelco HPLC gradient [19].

Each fish slurry sample was extracted in a $500 \mathrm{~mL}$ Pyrex borosilicate reflux system for $4 \mathrm{~h}$ and then ultrasonic (US) extractions were performed with an ultrasonic probe device (UP400S, Hielscher, Teltow ${ }^{\circledR}$, Teltow, Germany) with a glass reactor double chamber (with water cooling system) for ultrasonic flow. The US extractions were performed under controlled temperature conditions $\left(20 \pm 1.5^{\circ} \mathrm{C}\right)$ and a fixed $20 \mathrm{kHz}$, with a maximum power of $400 \mathrm{~W}$ and a surface emitter of 3.8 $\mathrm{cm}^{2}$. The ultrasonic probe was immersed in the slurry and the container was kept in the dark. US operations ran for $1 \mathrm{~min}$ followed by $2 \mathrm{~min}$ pauses, for half an hour. Weighed extracted samples 
were transferred into $50 \mathrm{~mL}$ polytetrafluoroethylene centrifuge tubes and centrifuged at $4000 \mathrm{rpm}$ for $10 \mathrm{~min}$ and the supernatant was decanted into a $50 \mathrm{~mL}$ test tube. The remaining sample precipitate was extracted and centrifuged again. Two extraction solvents were filtered through 0.45 and $0.20 \mu \mathrm{m}$ filters (Sartorius $A G^{\circledR}$, Gottingen, Germany) on ice, combined and then evaporated with a rotary evaporator at high vacuum pressure to almost dryness and re-dissolved in $10 \mathrm{~mL}$ of dichloromethane-methanol (40:60). The $10 \mathrm{~mL}$ samples were kept on ice until use.

The samples were then concentrated within C18SPE columns in fractions of $5 \mathrm{~mL}$. The C18 SPE column was equilibrated with type 1 (ultra pure) water from a Milli-Q water purification apparatus and methanol using the vacuum pump at minimum pressure. After passing the entire sample through the column it was eluted with $20 \mathrm{~mL}$ of a methanol-water $(80: 20, v / v)$ solvent mixture and then with a $30 \mathrm{~mL}$ dichloromethane-methanol (40:60) solvent mixture. Both eluates were collected separately and dried with a rotary evaporator at high vacuum pressure, then re-dissolved to $1 \mathrm{~mL}$ of methanol for analysis by the ultra high-performance liquid chromatography-tandem mass spectrometry (UHPLC-MS/MS) [20].

\subsection{Analysis of ECs}

The ultra high-performance liquid chromatography-tandem mass spectrometry (UHPLC/MS/MS) equipment and chromatographic conditions were used to characterize the ECs as analytes [21]. Eluted analytes were monitored by MS/MS using a Varian model $1200 \mathrm{~L}$ triple-quadrupole mass analyzer equipped with an electrospray interface (ESI). Additional instrumental parameters held constant for all analytes were as follows: nebulizing gas, $\mathrm{N}_{2}$ at 60 psi; drying gas, $\mathrm{N}_{2}$ at 19 psi; temperature, $300{ }^{\circ} \mathrm{C}$; needle voltage, $5000 \mathrm{~V} \mathrm{ESI+,} 4500 \mathrm{~V} \mathrm{ESI-;} \mathrm{declustering} \mathrm{potential,} 40 \mathrm{~V}$; collision gas, argon at 2.0 mTorr. The Ionization method selected for all the analytes was the ESI negative MS/MS analysis.

The identification and the quantification of these molecules was carried out using calibration curves and mass spectrum comparison with MERCK analytical standards: diclofenac sodium salt (329770242), ibuprofen sodium salt (329815360), ketorolac tris salt (24278503) and naproxen sodium salt (57654352). Standard stock solution of $2 \mathrm{mg} / \mathrm{mL}$ for each analyte was prepared by dissolving $200 \mathrm{mg}$ in $100 \mathrm{~mL}$ of methanol. In addition, intermediate standard solutions of $400 \mu \mathrm{g} / \mathrm{mL}$, $50 \mu \mathrm{g} / \mathrm{mL}$ and $2 \mu \mathrm{g} / \mathrm{mL}$ were prepared by diluting with methanol from the solution and stored at $4{ }^{\circ} \mathrm{C}$. Internal standards and surrogates for recovery rates were isotopically labeled ibuprofen- $\mathrm{d}_{3}$

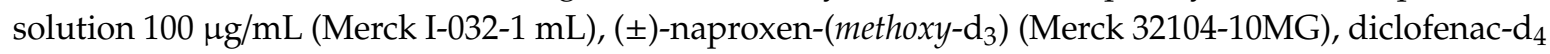
(Biosynth Carbosynth) FD165151-1MG and ketorolac tromethamine certified reference material cerilliant corp (Merck PHR1140-500MG). The latter was also used as an internal standard. Internal standards were used for each one of the analytes with $10 \mathrm{ng} / \mathrm{mL}$ for the determinations of \% Rec and -\%ME. Analytes specific limits of detection (LODs), limits of quantitation (LOQs) and method detection limits (MDLs) are defined and reported in Table 1. LOD was calculated as three times the standard deviation in the background signal observed for replicate analysis of a tissue blank. LOQ was calculated as ten times the standard deviation in the background signal observed for replicate analysis of a tissue blank. MDL was determined by multiplying the one-sided Student's $t$-statistic at the $99 \%$ confidence limit times the standard deviation observed for eight replicate analyses of a matrix spike (spiking level $10 \times \mathrm{MDL})$.

Table 1. Linear range, limits of detection (LOD), limits of quantitation (LOQ) and method detection limit (MDL) for target analytes in fish tissue samples.

\begin{tabular}{ccccc}
\hline Analyte & $\begin{array}{c}\text { Linear Range } \\
\text { (ng/g) }\end{array}$ & $\begin{array}{c}\text { LOD } \\
\text { (ng/g) }\end{array}$ & $\begin{array}{c}\text { LOQ } \\
\text { (ng/g) }\end{array}$ & $\begin{array}{c}\text { MDL } \\
\text { (ng/g) }\end{array}$ \\
\hline Diclofenac & $38.5-3000$ & 1.15 & 3.83 & 33.65 \\
Ibuprofen & $25.1-2700$ & 3.21 & 10.66 & 45.92 \\
Ketorolac & $14.0-2500$ & 1.32 & 4.44 & 40.88 \\
Naproxen & $45.8-3200$ & 0.97 & 3.25 & 27.93 \\
\hline
\end{tabular}


Mean limit of quantification for the analytical method: $0.5 \mathrm{ng} / \mathrm{g}$. Mean equipment detection limit: $0.02 \mathrm{ng} / \mathrm{g}$. Recovery rate for the four analytes (upper and lower limit values): (92\%, 95\%) $\pm 1.5 \%$. Matrix effect for the four analytes (upper and lower limit values): $(-9 \%,-2 \%) \pm 0.5 \%$ and correlation of determination $\mathrm{R}^{2}$ for the four analytes (upper and lower limit values): $(0.992,0.998)$.

\section{Calculation}

To quantify the bioaccumulative potential risk (BPR) of the studied pollutants in the environment, the human and ecological risk factors were calculated using Equations (1)-(5) $[9,22,23]$.

\subsection{Ecological Risk Factors}

$$
\mathrm{BCF}=\frac{\mathrm{Ct}}{\mathrm{Ce}} \times 1000
$$

where $\mathrm{BCF}$ is the bioconcentration factor. $\mathrm{Ct}$ is the $\mathrm{EC}$ concentration in tissue; Ce is the EC concentration in the effluent.

$$
C_{f}=\frac{C_{m}}{C_{r e f}}
$$

where $C_{f}$ is the contamination factor. $C_{m}$ is the mean $\mathrm{EC}$ concentration in the medium; $C_{r e f}$ is the $\mathrm{EC}_{50}$ for each pharmaceutical.

$$
E_{p}=B C F \times C_{f}
$$

where $E_{p}$ is the ecological potential risk for individual NSAIDs.

\subsection{Human Health Risk Factor}

$$
H R F: I_{r} \times T_{e} \times T_{p}
$$

where HRF is the human health risk factor for each contaminant; $I_{r}$ is the ingestion rate, $T_{e}$ is the exposure frequency, $T_{p}$ is the exposure period.

\subsection{Bioaccumulative Potential Risk}

$$
B P R=\log _{10}\left(\sum_{i=1}^{m} E_{p} \times H R F\right)
$$

where $B P R$ is the bioaccumulative potential risk; $H R F$ is the average human health risk factor for the NSAIDs detected.

For the calculation of the bioaccumulative potential risk, the pharmacokinetic properties of nonsteroidal anti-inflammatory drugs were considered (Table 2).

Table 2. Pharmacokinetic characteristics of contaminants.

\begin{tabular}{ccccc}
\hline Contaminant & $\begin{array}{c}\text { Molecular } \\
\text { Formula }\end{array}$ & pKa & $\begin{array}{c}\text { Solubility in } \\
\text { Water }(\mathbf{m g} / \mathbf{L})\end{array}$ & $\begin{array}{c}\mathbf{E C}_{\mathbf{5 0}} \\
\text { Daphnia Magna 48 h } \\
\mathbf{( m g / L )}\end{array}$ \\
\hline Diclofenac & $\mathrm{C}_{14} \mathrm{H}_{11} \mathrm{NCl}_{2} \mathrm{O}_{2}$ & 4.15 & 19.4 & $68.30[24]$ \\
Ibuprofen & $\mathrm{C}_{13} \mathrm{H}_{18} \mathrm{O}_{2}$ & 5.2 & 21 & $101.2[25]$ \\
Ketorolac & $\mathrm{C}_{15} \mathrm{H}_{13} \mathrm{NO}_{3}$ & 3.84 & 15 & $109.2[24]$ \\
Naproxen & $\mathrm{C}_{14} \mathrm{H}_{14} \mathrm{O}_{3}$ & 4.15 & 15.9 & $166.3[25]$ \\
\hline
\end{tabular}


The index proposed by Hakanson (Table 3) was used to establish the level of bioaccumulative potential risk of the contaminants.

Table 3. Hakanson classification.

\begin{tabular}{cc}
\hline BPR & Risk Classification \\
\hline$<1$ & Low \\
$1-10$ & Moderate \\
$11-100$ & Considerable \\
$>100$ & Very High \\
\hline
\end{tabular}

\section{Results and Discussion}

As suspected, it was possible to identify the presence of the four targeted NSAIDs within all samples. The average concentrations found within the tissues of the fish species at both sites are presented in the following graphs (Figures 2 and 3). The standard error of the mean (SEM) was calculated using $\mathrm{N}=16$, which represents the number of analytical samples per specimen.

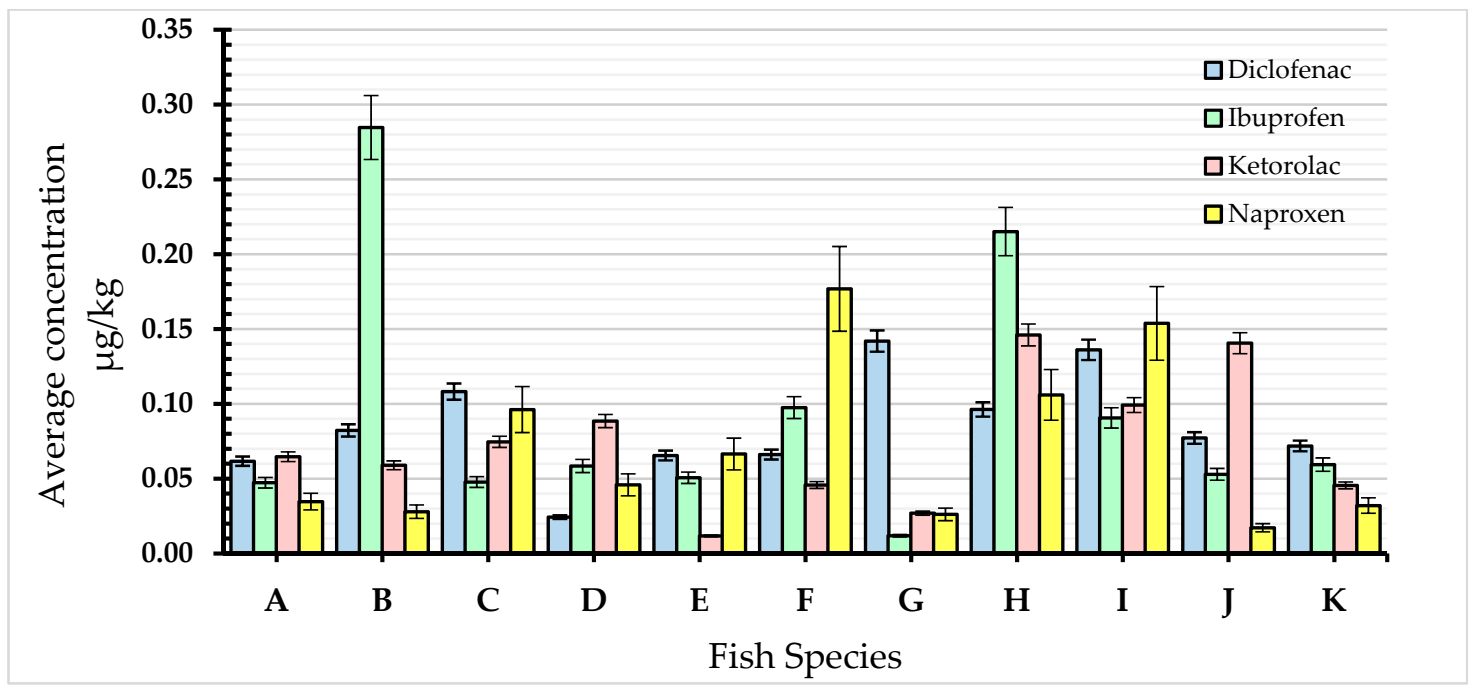

Figure 2. Concentration of nonsteroidal anti-inflammatory drugs (NSAIDs) at site "A". Fish species: A: Acanthurus xanthopterus, B: Ariopsis felis, C: Caranx caninus, D: Chanos chanos, E: Gerres cinereus, F: Haemulopsis elongatus, G: Lutjanus peru, H: Mugil curema, I: Paralichthys californicus, J: Pseudupeneus grandisquamis, K: Selene peruviana. 


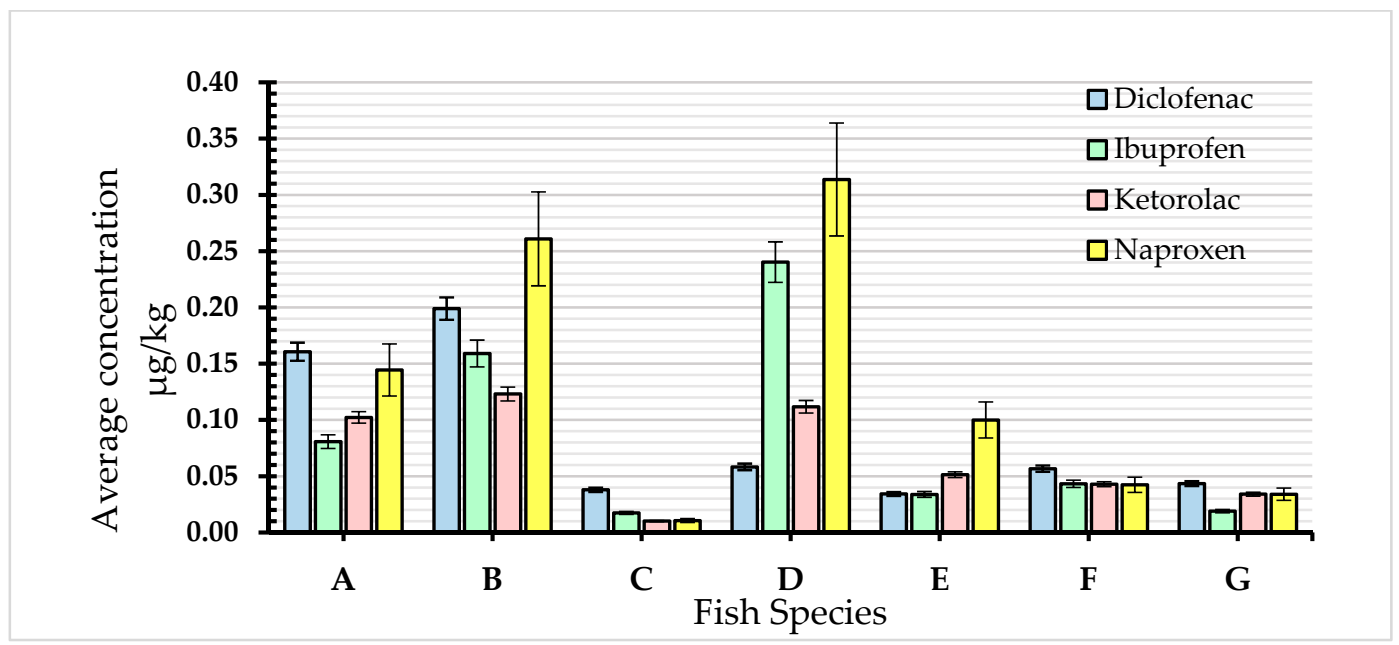

Figure 3. Concentration of NSAIDs at site "B". Fish species A: Ariopsis felis, B: Caranx caninus, C: Centropomus robalito, D: Synodus lacertinus, E: Lutjanus peru, F: Mugil curema, G: Sarda orientalis.

The results of the analysis performed on the muscle tissue of the fishes demonstrated the presence of the pharmaceuticals diclofenac, ibuprofen, ketorolac and naproxen in all the species analyzed at both study sites. As shown in Figures 2 and 3, the pollutants found in higher concentrations were ibuprofen for the "A" study site $(0.01-0.31 \mu \mathrm{g} / \mathrm{kg})$ and naproxen for the "B" study site $(0.01-0.28 \mu \mathrm{g} / \mathrm{kg})$, which suggests that these are the most persistent compounds in the studied group, or they are the most consumed drugs at the study sites.

Adverse effects can be inferred in fish exposed to environmental concentrations of NSAIDs at the study sites, like mild to moderate alterations in fish liver and gills [26]. These compounds also have the potential to affect biomarkers associated with sexual differentiation and gametogenesis of fish, acting as estrogenic endocrine disruptors (EDC) [27]. Other studies show that ibuprofen modulates the production of hormones and the transcription of related genes of the hypothalamic-pituitary-gonadal axis in a sex-dependent manner, which could cause adverse effects on reproduction and offspring development in the fish species analyzed [28]. In blood, ketorolac acts as a genotoxic, increasing the frequency of micronuclei for some fish species and inducing oxidative damage (increased lipid peroxidation, hydroperoxide content and carbonyl protein content) [8].

Tables 4 and 5 present the average values of the bioconcetration (BCF) and bioaccumulative potential risk (BPR) for the NSAIDs, calculated using Equations (1)-(5) and classified using the Hakanson index. Values were calculated using the tissue sample analysis results, with the average values of NSAID concentrations in effluents reported in 2019 in [21] and the parameters in Table 2. 
Table 4. Average values of bioconcentration (BCF) and bioaccumulative potential risk (BPR) at site "A".

\begin{tabular}{cccc}
\hline \multicolumn{4}{c}{ Site "A" } \\
\hline Fish Species & BCF & BPR & Classification \\
\hline Acanthurus xanthopterus & 8.4 & 26.7 & Considerable \\
Ariopsis felis & 19.3 & 0.0 & $\mathrm{Nd}$ \\
Caranx caninus & 9.3 & 0.0 & $\mathrm{Nd}$ \\
Chanos chanos & 11.1 & 7.1 & Moderate \\
Gerres cinereus & 3.6 & 0.0 & $\mathrm{Nd}$ \\
Haemulopsis elongatus & 9.0 & 0.0 & Nd \\
Lutjanus peru & 3.1 & 1.9 & Moderate \\
Mugil curema & 24.1 & 0.0 & $\mathrm{Nd}$ \\
Paralichthys californicus & 13.7 & 0.0 & $\mathrm{Nd}$ \\
Pseudupeneus & 15.7 & 0.5 & Low \\
grandisquamis & 7.1 & 0.0 & $\mathrm{Nd}$ \\
Selene peruviana & & &
\end{tabular}

Nd: Not able to determine.

Table 5. Average values of BCF and BPR at site "B".

\begin{tabular}{cccc}
\hline \multicolumn{4}{c}{ Site “B" $^{\text {"B }}$} \\
\hline Fish Species & BCF & BPR & Classification \\
\hline Ariopsis felis & 13.5 & 26.7 & Considerable \\
Caranx caninus & 19.3 & 0.0 & Nd \\
Centropomus robalito & 1.8 & 0.0 & Nd \\
Synodus lacertinus & 22.1 & 7.1 & Moderate \\
Lutjanus peru & 6.5 & 0.0 & Nd \\
Mugil curema & 6.1 & 0.0 & Nd \\
Sarda orientalis & 4.1 & 1.9 & Moderate \\
\hline
\end{tabular}

Nd: Not able to determine.

The estimated bioaccumulation factors indicate that the species classified as carnivores (Caranx caninus, Synodus lacertinus) and detritivores (Ariopsis felis, Mugil curema) accumulated the greatest quantity of NSAIDs (Tables 4 and 5), indicating the presence of these compounds in lagoon sediments, as well as the accumulation of these drugs along the trophic network of these aquatic ecosystems. The results shown in Tables 4 and 5 suggest that the species of commercial interest, Lutjanus peru and Chanos chanos [29] at site A, and Synodus lacertinus and Sarda orientlais [30] at site B, pose a moderate BPR.

To estimate the risk to human health, the consumption standards developed by the EPA were used. These guidelines assume a person to be $70 \mathrm{~kg}$ with a 70-year lifespan, consuming an average of 17.5 and $142.4 \mathrm{~g}$ of fish per day for recreational and subsistence fishers, respectively [12]. The calculated average values for the human health risk factor $(\mathrm{HRF})$ were $0.1( \pm 0.03)$ for recreational fishers and $0.2 \pm(0.02)$ for subsistence fishers in all species studied.

The obtained HRF values indicate no direct risk to human health, as these values represent consumption averages over a 70-year lifespan. However, the constant ingestion of food contaminated with NSAIDs, in this case the fish muscle, can gradually decrease the effect of the drugs [31] as well as increase resistance and/or tolerance to the same compounds [32]. This could result in increased consumption of these compounds, causing higher concentrations of these pollutants in wastewater discharges and subsequently in natural water bodies.

\section{Conclusions and Comments}

The BPR, estimated by calculating the environmental risk factor and the potential risk to human health, is used as an environmental indicator to evaluate the toxicity of four NSAIDs (diclofenac, ibuprofen, ketorolac and naproxen) in wastewater discharged into estuarine coastal ecosystems in the 
central Mexican Pacific. The muscle tissues of 14 species of fish were analyzed, all of which presented the four contaminants at different concentrations $(0.1-0.31 \mu \mathrm{g} / \mathrm{kg})$.

The calculation of the BPR revealed the potential impact of the NSAIDs on the ecology of these coastal lagoons, as well as the possibility of contamination and risks to human health caused by residues of the same chemical contaminants in food.

This study emphasizes the importance of carrying out additional research on the toxic effects of these types of pollutants in higher organisms that inhabit estuarine and coastal ecosystems. Future research should focus on the analysis of other contaminants considered as emergent (hormones, analgesics, psychotropic drugs and antibiotics), especially those that are released into the environment in large quantities and that are expected to have environmental effects, as well as focus on the study of origins, means of propagation and physicochemical characteristics.

To corroborate and identify potential effects produced by NSAIDs in the biota of these ecosystems, the unknown effects and potential risks for other organisms (invertebrates, fish, birds that feed on fish) must be assessed. We propose the development of bioassays that evaluate environmental concentrations in species of interest. Another line of research should focus on the effects of these contaminants for a better understanding of the species that are at risk.

In order to evaluate the contamination and exposure of the ECs in surface water bodies in the near future, research should be carried out to define the sampling period and duration, the type of species (and trophic levels) to be monitored and the tissues/organs that should be collected for a better understanding of the pharmaceutical's destination. Although many organizations have established toxicological and environmental health standards, there are no environmental toxicity indicators of this type in Mexico. This study provides valuable information to establish new environmental quality criteria, as well as to propose preventive and corrective measures in order to restrict and reduce the amounts of these emerging pollutants released into the environment.

Author Contributions: M.Á.A.-P.: writing-original draft preparation, methodology and investigation. E.R.-A.: methodology and investigation. J.A.M.-P.: conceptualization, resources and supervision. M.M.M.-M.: formal analysis and resources. M.V.-G.: formal analysis and resources. C.L.-C.: formal analysis and resources. E.G.-D.: visualization and supervision F.d.A.S.-B.: investigation and validation. A.T.-G.: conceptualization, supervision and validation. All authors have read and agreed to the published version of the manuscript.

Funding: This work was mainly funded by the Research and Postgraduate Secretariat of the National Polytechnic Institute (SIP-IPN), Mexico (No. 20180081, 20190101, 20200598) and supported by National Council for Science and Technology (CONACyT), Mexico.

Acknowledgments: Special thanks to Eva Rose Kozak and Javier Agustín Flores. This research was carried out according to the guidelines and approval of the committee for bioethics in the research of the Department of Studies for the Sustainable Development of Coastal Zones, University of Guadalajara (DEDSZC-UdG).

Conflicts of Interest: The authors declare that they have no conflicts of interest.

\section{References}

1. Thompson, E. Indicators of Anthropogenic Change and Biological Risk in Coastal Aquatic Environments Earth Systems and Environmental Sciences. Encyclopedia of the Anthropocene. Elsevier 2018, 3, 97-124.

2. Omar, T.F.T.; Aris, A.Z.; Yusoff, F.M.; Mustafa, S. Occurrence, distribution, and sources of emerging organic contaminants in tropical coastal sediments of anthropogenically impacted Klang River estuary, Malaysia. Mar. Pollut. Bull. 2017, 131, 284-293. [CrossRef] [PubMed]

3. Mankes, F.; Silver, C. Pharmaceutical Dispensing and Wasting In Health Care Facilities, Amounts, Costs and Evaluation of Potential Ecologic Effects. SOJ Pharm. Pharm. Sci. 2017, 4, 1-32. [CrossRef]

4. Richardson, S.D.; Kimura, S.Y. Water analysis: Emerging contaminants and current issues. Anal. Chem. 2016, 88, 546-582. [CrossRef] [PubMed]

5. Gros, M.; Petrovic, M.; Ginebreda, A.; Barcelo, D. Removal of pharmaceuticals during wastewater treatment and environmental risk assessment using hazard indexes. Environ. Int. 2009, 36, 15-26. [CrossRef] [PubMed]

6. Schröder, P.; Helmreich, B.; Skrbic, B.; Carballa, M.; Papa, M.; Pastore, C.; Emre, Z.; Oehmen, A.; Langenhoff, A.; Molinos, M.; et al. Status of hormones and painkillers in wastewater effluents across several European 
states-Considerations for the EU watch list concerning estradiols and diclofenac. Environ. Sci. Pollut. Res. 2016, 23. [CrossRef] [PubMed]

7. Wolf, J.; Ruehl-Fehlert, C.; Segner, H.; Weber, K.; Hardisty, J. Pathology working group review of histopathologic specimens from three laboratory studies of diclofenac in trout. Aquat. Toxicol. 2013, 146, 127-136. [CrossRef]

8. Galar-Martínez, M.; García-Medina, S.; Gómez-Olivan, L.M.; Pérez-Coyotl, I.; Mendoza-Monroy, D.J.; Arrazola-Morgain, R.E. Oxidative stress and genotoxicity induced by ketorolac on the common carp Cyprinuscarpio. Environ. Toxicol. 2016, 1035-1043. [CrossRef]

9. Al-Shami, S.; Yap, C.; Wong, K.; Al-qahtani, S.; Alsabih, I.; Al-Zaqri, N. Ecological risk assessments of heavy metals in surface sediments collected from Haqal coastal waters (Tabuk Region), Saudi Arabia. Appl. Ecol. Environ. Res. 2019, 17, 3065-3075. [CrossRef]

10. Stadnicka, J.; Schirmer, K.; Ashauer, R. Predicting concentrations of organic chemicals in fish by using toxicokinetic models. Environ. Sci. Technol. 2012, 46, 3273-3280. [CrossRef]

11. Zenker, A.; Cicero, M.; Prestinaci, F.; Bottoni, P.; Carere, M. Bioaccumulation and biomagnification potential of pharmaceuticals with a focus to the aquatic environment. J. Environ. Manag. 2014, 133, 378-387. [CrossRef] [PubMed]

12. USEPA. Short-Term Methods for Estimating the Chronic Toxicity of Effluents and Receiving Waters to Freshwater Organisms, 4th ed.; US Environmental Protection Agency: Wahington, DC, USA, 2002.

13. Hazrat, A.; Ezzat, K.; Ikram, I. Environmental Persistence, Toxicity, and Bioaccumulation. J. Environ. Chem. Ecotoxicol. 2019. [CrossRef]

14. Tonnelier, A.; Coecke, S.; Zaldívar, J.-M. Screening of chemicals for human bioaccumulative potential with a physiologically based toxicokinetic model. Arch. Toxicol. 2011, 86, 393-403. [CrossRef]

15. INEGI. Intercensal Survey of Population and Housing. 2015; National Institute of Statistic and Geography, México 2015. Available online: http://www.inegi.org.mx (accessed on 5 April 2020).

16. Ramsar. Ramsar Sites List. Ramsar Convention. 2019. Available online: https://www.ramsar.org/document/ the-list-of-wetlands-of-international-importance-theramsar-list (accessed on 5 April 2020).

17. Jenkins, J.; Bart, H.; Bowker, J.; Bowser, J.; Macmillan, J.; Nickum, J.; Rose, J.; Sorensen, P. Guidelines for the Use of Fishes in Research; American Fisheries Society: Bethesda, MD, USA, 2014.

18. Huerta, B.; Rodríguez-Mozaz, S.; Lazorchak, J.; Barcelo, D.; Batt, A.; Wathen, J.; Stahl, L. Presence of pharmaceuticals in fish collected from urban rivers in the U.S. EPA 2008-2009 National Rivers and Streams Assessment. Sci. Total Environ. 2018, 634, 542-549. [CrossRef] [PubMed]

19. Ramirez, A.; Mohammad, A.; Mottaleb, B.; Brooks, W.; Chambliss, K. Analysis of Pharmaceuticals in Fish Using Liquid Chromatography-Tandem Mass Spectrometry. Anal. Chem. 2007, 79, 3155-3163. [CrossRef]

20. Padrón, M.E.; Afonso-Olivares, C.; Sosa-Ferrera, Z.; Santana-Rodríguez, J. Microextraction techniques coupled to liquid chromatography with mass spectrometry for the determination of organic micropollutants in environmental water samples. Molecules 2014, 19, 10320-10349. [CrossRef] [PubMed]

21. Arguello-Pérez, M.; Mendoza-Pérez, J.; Tintos-Gómez, A.; Ramírez-Ayala, E.; Godínez-Domínguez, E.; Silva-Bátiz, F. Ecotoxicological Analysis of Emerging Contaminants from Wastewater Discharges in the Coastal Zone of Cihuatlán (Jalisco, Mexico). Water 2019, 11, 1386. [CrossRef]

22. Hakanson, L. An Ecological Risk Index for Aquatic Pollution Control-A Sedimentological Approach. Water Res. 1980, 14, 975-1001. [CrossRef]

23. Grabicova, K.; Lindberg, R.; Östman, M.; Grabic, R.; Randak, T.; Joakim Larsson, D.G.; Fick, J. Tissue-specific bioconcentration of antidepressants in fish exposed to effluent from a municipal sewage treatment plant. Sci. Total Environ. 2014, 488-489, 46-50. [CrossRef]

24. Carlsson, G.; Norrgren, L. Synthetic musk toxicity to early life stages of zebrafish (Danio rerio). Arch. Environ. Contam. Toxicol. 2004, 46, 102-105. [CrossRef]

25. Cleuvers, M. Mixture Toxicity of the Anti-Inflammatory Drugs Diclofenac, Ibuprofen, Naproxen, and Acetylsalicylic Acid. Ecotoxicol. Environ. Saf. 2004, 59, 309-315. [CrossRef]

26. Mohebi Derakhsh, P.; Mashinchian Moradi, A.; Sharifpour, I.; Jamili, S. Toxic effects of diclofenac on gills, liver and kidney of Cyprinus carpio. Iran. J. Fish. Sci. 2018, 19, 735-747. [CrossRef]

27. Keitel-Gröner, F.; Höhne, C.; Kleiner, W.; Kloas, W. Chronic diclofenac exposure affects gill integrity and pituitary gene expression and displays estrogenic activity in nile tilapia (Oreochromisniloticus). Chemosphere 2017, 166. [CrossRef] 
28. Ji, K.; Liu, X.; Lee, S.; Kang, S.; Kho, Y.; Choi, K. Effects of non-steroidal anti-inflammatory drugs on hormones and genes of the hypothalamic-pituitary-gonad axis, and reproduction of zebrafish. J. Hazard. Mater. 2013, 254-255, 242-251. [CrossRef] [PubMed]

29. Espino-Barr, E.; Cabral-Solís, E.G.; García-Boa, A.; Puente-Gómez, M. Marine Species with Commercial Value on the Coast of Jalisco, Mexico. SAGARPA; National Fisheries Institute: Washington, DC, USA, 2004; Volume 145.

30. Espino-Barr, E.; Cruz-Romero, M.; García-Boa, A. Marine Species with Commercial Value on the Coast of Colima, Mexico. CONABIO; National Fisheries Institute: Washington, DC, USA, 2003; Volume 115.

31. Schrenk, D.; Cartus, A. Chemical Contaminants and Residues in Food, 2nd ed.; Woodhead Publishing: Cambridge, UK, 2017.

32. Tsagareli, M.; Tsiklauri, N.; Nozadze, I.; Gurtskaia, G. Tolerance effects of non-steroidal anti-inflammatory drugs microinjected into central amygdala, periaqueductal grey, and nucleus raphe: Possible cellular mechanism. Neural Regen. Res. 2012, 7, 1029-1039. [CrossRef]

(C) 2020 by the authors. Licensee MDPI, Basel, Switzerland. This article is an open access article distributed under the terms and conditions of the Creative Commons Attribution (CC BY) license (http://creativecommons.org/licenses/by/4.0/). 